doc dr. sc. Sanja Knežević

doc. dr. sc. Lena Sigurnjak²

Iva Bilić, bacc. oec. ${ }^{3}$

\title{
UTJECAJ KORONA PANDEMIJE NA (NE)STABILNOST RADNIH MJESTA U ISTOČNOJ HRVATSKOJ
}

\author{
Prethodno priopćenje / Preliminary communication \\ UDK/UDC: 331.52:616.2(497.5) \\ DOI: $10.51650 /$ ezrvs.15.3-4.2 \\ Primljeno / Received: 1/10/2021 \\ Prihvaćeno / Accepted: 8/11/2021
}

\begin{abstract}
Korona pandemija pretvorila se u globalnu ekonomsku krizu, dovodeći u opasnost prije svega zdravlje, prihode milijuna ljudi diljem svijeta te radna mjesta. Svrha rada je razumijevanje utjecaja korona pandemije na stabilnost radnih mjesta. Cilj rada je analizirati utjecaj korona pandemije na stabilnost radnih mjesta u pet županija Istočne Hrvatske. U istraživanje je uključena analiza anketnog upitnika koji su popunila 615 ispitanika iz 5 županija Istočne Hrvatske te prikupljenih statističkih podataka i relevantne stručne literature. Ograničenje rada je činjenica da pandemija još uvijek traje, a dostupni podaci su još uvijek ograničeni. Prema rezultatima istraživanja, anketirani ispitanici smatraju da korona pandemija ima veliki utjecaj na nestabilnost radnih mjesta u Istočnoj Hrvatskoj.
\end{abstract}

Ključne riječi: pandemija, radna mjesta, nezaposlenost, Istočna Hrvatska.

\section{Uvod}

Istočna Hrvatska sa svojih pet županija: Brodsko-posavskom, Osječko-baranjskom, Požeško-slavonskom, Virovitičko-podravskom i Vukovarsko-srijemskom, najslabije je razvijena regija. „Čak četiri od pet slavonskih županija nalaze se na razini ispod 60 \% prosječne razine razvijenosti $\mathrm{RH}$ i zauzimaju četiri posljednja mjesta na ljestvici razvijenosti županija" (HGK, 2020, str. 10).

Jedan od glavnih problema je visoka stopa nezaposlenosti. Nezaposlenošću se ukazuje na osnovne društvene i ekonomske probleme. Nedostatak radnih mjesta tako uvjetuje odlazak mladog stanovništva iz Istočne Hrvatske prema ekonomski atraktivnijim područjima. Pandemija uzrokovana koronavirusom (COVID - 19) dodatno različito utječe na razne sektore i poduzeća. Radi sprečavanja snažnijih negativnih posljedica širenja korona pandemije na gospodarstvo, Vlada RH je donijela niz mjera za pomoć gospodarstvu.

\footnotetext{
1 Sveučilište u Slavonskom Brodu; e-mail: sknezevic@unisb.hr

2 Sveučilište u Slavonskom Brodu; e-mail: Isigurnjak@unisb.hr

3 Sveučilište u Slavonskom Brodu; e-mail: ibilic@unisb.hr
} 


\section{Očuvanje radnih mjesta}

Mjere aktivnog zapošljavanja u Hrvatskoj jedan su od najefikasnijih alata za razvoj tržišta rada i poduzetništva te povećavanja zapošljavanja. Kroz mjere aktivnog zapošljavanja 2016. - 2020. „u četiri godine dodijeljeno je 4,7 mlrd kn potpora za 149.580 korisnika. Plan za 2021. je 38.000 korisnika i 1.3 mlrd kn poticaja." (Mjere aktivnog zapošljavanja, 2021. )

Uslijed posljedica uzrokovanih pandemijom koronavirusa u ožujku 2020. godine usvojene su nove mjere aktivne politike zapošljavanja s ciljem zadržavanja radnih mjesta u najugroženijim sektorima. U promatranom razdoblju „od ožujka 2020. do svibnja 2021. ukupno je isplaćeno 11.054.880.619 kn“ (Skupna statistika isplata i radnika u potporama za očuvanje radnih mjesta - ožujak 2020.-svibanj 2021., 2021.) Najveći udio isplata od $48 \%$ otišao je na mikropoduzetnike. Upravo zahvaljujući potporama, nezaposlenost u Hrvatskoj je ipak manja nego u razdoblju početka pandemije. U tablici koja slijedi prikazana je nezaposlenost u županijama Istočne Hrvatske.

Tablica 1. Nezaposlenost u Istočnoj Hrvatskoj od 2016. - 2020. godine

\begin{tabular}{|c|c|c|c|c|c|}
\hline Godina & \multirow{2}{*}{2016.} & \multirow{2}{*}{2017.} & \multirow{2}{*}{2018.} & \multirow{2}{*}{2019.} & \multirow{2}{*}{2020.} \\
\hline Županija & & & & & \\
\hline Virovitičko-podravska & 8146 & 6559 & 5154 & 4332 & 4706 \\
\hline Požeško-slavonska & 4411 & 3646 & 2873 & 2389 & 2872 \\
\hline Brodsko-posavska & 10591 & 8545 & 7026 & 5820 & 6732 \\
\hline Osječko-baranjska & 28062 & 23453 & 19113 & 16193 & 17369 \\
\hline Vukovarsko-srijemska & 14351 & 11569 & 8782 & 6642 & 7606 \\
\hline Ukupno Hrvatska & 241860 & 193967 & 153542 & 128650 & 150824 \\
\hline
\end{tabular}

Tablica 1. prikazuje nezaposlenost u županijama Istočne Hrvatske. Osječko-baranjska županija je s najvećim brojem registrirane nezaposlenosti kroz promatrano razdoblje dok je najmanji broj nezaposlenih imala Požeško-slavonska županija. Visoka nezaposlenost povećava daljnju nesigurnost, potiče emigraciju, te zaoštrava ekonomske i socijalne probleme. U Istočnoj Hrvatskoj se „do 2030. godine očekuje daljnji demografski pad, i to na 656540 stanovnika što u odnosu na popis iz 2011. godine predstavlja depopulaciju od čak 19,5 posto" (Živić, 2017).

„Vlada Republike Hrvatske 2017. je godine pokrenula Projekt Slavonija, Baranja i Srijem ne bi li toj regiji pomogla u povećanju učinkovitosti i djelotvornosti korištenja sredstava EU-a. Inicijative iz ovoga projekta pripomažu kataliziranju novih ulaganja privatnog sektora, povećanju zaposlenosti i poboljšanju životnih uvjeta“ (World Bank, 2017). 
Tablica 2. Nezaposlenost u Istočnoj Hrvatskoj u svibnju 2019., 2020. i 2021.

\begin{tabular}{|l|c|c|c|}
\hline \multirow{yyn}{*}{ Mjesec/godina } & \multirow{2}{*}{ Svibanj 2019. } & Svibanj 2020. & Svibanj 2021. \\
\cline { 1 - 3 } Virovitičko-podravska & 3995 & 4886 & 4196 \\
\hline Požeško-slavonska & 2131 & 3013 & 2301 \\
\hline Brodsko-posavska & 5581 & 6931 & 6472 \\
\hline Osječko-baranjska & 15126 & 17821 & 15876 \\
\hline Vukovarsko-srijemska & 6111 & 8067 & 6418 \\
\hline Ukupno Hrvatska & 116466 & 157839 & 138030 \\
\hline
\end{tabular}

Izvor: autorice prema Mjesečni statistički bilten $(2019,2020,2021)$

Tablica 2. prikazuje broj nezaposlenih i to u svibnju 2019., 2020., i 2021. godine. Broj nezaposlenih u svim županijama je 2020.godine u samom jeku korona pandemije porastao dok je u svibnju 2021. taj broj smanjen u svim navedenim županijama te ukupno na razini Hrvatske. Najveći gubitnici korona pandemije su u većini zaposleni u turizmu, ugostiteljstvu i drugim, uslužnim djelatnostima.

\section{Metodologija istraživanja}

Uzorak čine 615 ispitanika iz pet županija Istočne Slavonije: Virovitičko-podravske županije, Brodsko-posavske županije, Vukovarsko-srijemske, Osječko-baranjske županije, županije i Požeško-slavonske županije. Uzorak čine svi ispitanici koji su stariji od 18 godina, te drugih ograničenja nije bilo.

Istraživanje percepcije o utjecaju korona pandemije na (ne)stabilnost radnih mjesta u Istočnoj Hrvatskoj obuhvatilo je 615 ispitanika koji su od 19. travnja 2021. godine do 20. svibnja 2021. godine odgovarali na pitanja iz online upitnika na društvenim mrežama. Promatrano razdoblje je od ožujka 2020. do svibnja 2021. Mišljenje ispitanika izraženo u anketnom upitniku predstavlja skup kvalitativnih podataka za cije prikupljanje je primijenjena Likertova skala s intervalom 1 do 5 na način da su ispitanici trebali za svako pitanje zaokružiti broj za koji smatraju da najbolje opisuje u kojoj mjeri pojedini segmenti utječu na (ne)stabilnost radnih mjesta u uvjetima korona pandemije. Dodatno, u upitniku je bilo 5 pitanja koja su se odnosila na demografske karakteristike ispitanika/ispitanica (spol, starost, završena škola, zanimanje, županija prebivališta). Anketni upitnik se sastojao od 3 dijela: 1. zajednički dio koji ispunjavaju svi ispitanici, zatim se ovisno o odgovoru na pitanje o statusu zaposlenja prelazi na 2. dio ankete koji je bio samo za zaposlene ispitanike, ili na 3. dio ako su ispitanici nezaposleni.

Ograničenje istraživanja predstavlja činjenica kako je anketni upitnik poveden elektroničkim putem, kao i to da pandemija još uvijek traje.

\section{Rezultati i rasprava}

Tablica 3. prikazuje demografska obilježja uzorka. Najviše ispitanika dolazi iz Brodskoposavske županije (43,9\%), zatim iz Osječko-baranjske županije (20,3 \%), iz Vukovarsko-srijemske županije (15\%), iz Požeško-slavonske županije (13,2 \%) te iz Virovitičko-podravske županije $(7,6 \%)$ ispitanika. Čak $43,6 \%$ ispitanika je nezaposleno, $35,1 \%$ je zaposleno je u struci 
i 21,3\%, je zaposleno, ali ne u struci. Najveći udio nezaposlenih s obzirom na ukupan broj ispitanika iz navedenih županija je iz Virovitičko-podravske županije (57\%) te iz Vukovarskosrijemske (54\%), dok je najmanji udio iz Brodsko- posavske županije.

Tablica 3. Demografska obilježja uzorka

\begin{tabular}{|c|c|c|c|}
\hline & & $\mathbf{N}$ & $\%$ \\
\hline \multirow{2}{*}{ Spol } & ženski & 407 & 66,2 \\
\hline & muški & 208 & 33,8 \\
\hline \multirow{5}{*}{ Dob } & $18-30$ & 364 & 59,2 \\
\hline & $31-40$ & 138 & 22,4 \\
\hline & $41-50$ & 73 & 11,9 \\
\hline & $51-60$ & 31 & 5 \\
\hline & $60>$ & 9 & 1,5 \\
\hline \multirow{5}{*}{ Županija } & Brodsko-posavska & 270 & 43,9 \\
\hline & Osječko- baranjska & 125 & 20,3 \\
\hline & Požeško-slavonska & 81 & 13,2 \\
\hline & Vukovarsko-srijemska & 92 & 15 \\
\hline & Virovitičko podravska & 47 & 7,6 \\
\hline \multirow{3}{*}{ Zaposlenost } & nezaposleno & 268 & 43,6 \\
\hline & zaposleno u struci & 216 & 35,1 \\
\hline & zaposleno, ali ne u struci & 131 & 21,3 \\
\hline
\end{tabular}

Izvor: autorice

$43,3 \%$ nezaposlenih ispitanika smatra da je upravo pandemija uzrok njihove nezaposlenosti, dok 56,7\% ispitanika smatra da pandemija ipak nije razlog njihove nezaposlenosti, nego neki drugi razlozi.

Grafikon 1. Stupanj aktivnosti traženja posla ispitanika

Ako aktivno tražite posao, u kojoj mjeri aktivno tražite posao u vrijeme korona pandemije (od ožujka 2020.-svibnja 2021.) ?

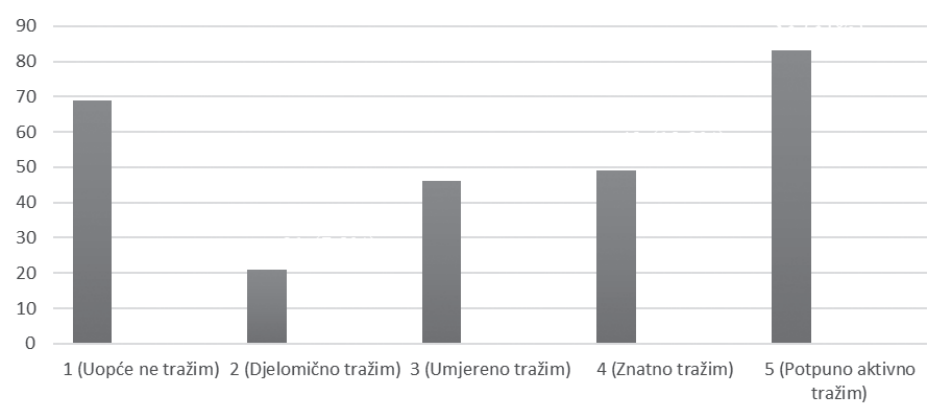

Izvor: autorice 
U grafikonu 1. prikazano je u kojoj mjeri ispitanici aktivno traže posao u vrijeme korona pandemije (od ožujka 2020-svibnja 2021.) Zabilježen je odgovor 268 ispitanika. Najveći broj ispitanika 83 (31\%) potpuno aktivno traži posao, ispitanici koji uopće ne traže posao 69 $(25,7 \%)$, ispitanici koji znatno traže posao 49 (18,3\%), ispitanici koji umjereno traže posao 46 $(17,2)$ i ispitanici koji djelomično traže $21(7,8)$.

Grafikon 2. Mišljenje ispitanika o zapošljavanju u periodu korona pandemije u odnosu na prije

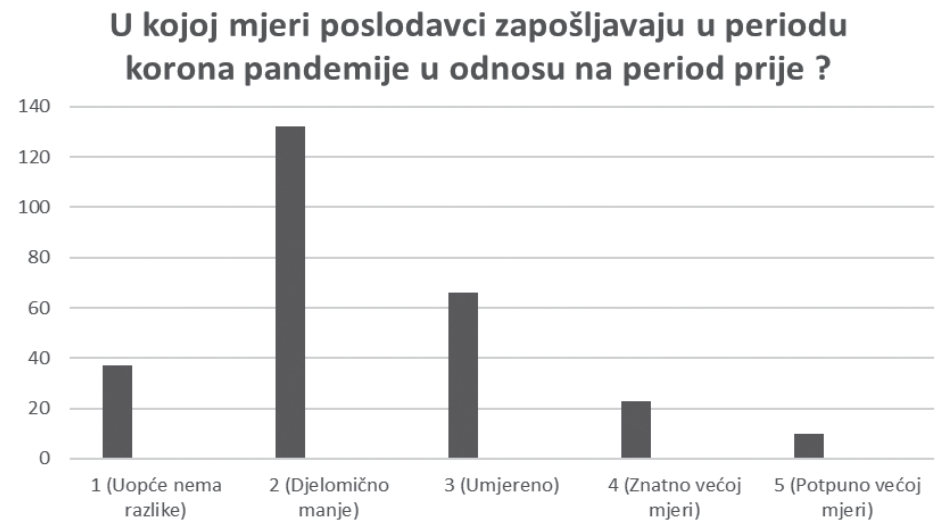

Izvor: autorice

U grafikonu 2. prikazano je mišljenje ispitanika u kojoj mjeri poslodavci zapošljavaju u periodu korona pandemije u odnosu na period prije. Zabilježen je odgovor 268 ispitanika. Najviše ispitanika 132 (49,3\%) smatra da djelomično manje poslodavci zapošljavaju, ispitanici $66(24,6)$ koji smatraju da poslodavci umjereno zapošljavaju u periodu korona pandemije u odnosu na period prije, ispitanici koji smatraju da uopće nema razlike u zapošljavanju 37 $(13,8 \%)$, ispitanici koji smatraju da poslodavci zapošljavaju u znatno većoj mjeri $23(8,6 \%)$ i ispitanici koji smatraju da poslodavci zapošljavaju u potpuno većoj mjeri 10 (3,7\%).

Grafikon 3. Mišljenje ispitanika o objavljivanim oglasima iz njihove struke

U kojoj mjeri su objavljeni oglasi za zapošljavanje iz Vaše struke u periodu korona pandemije?

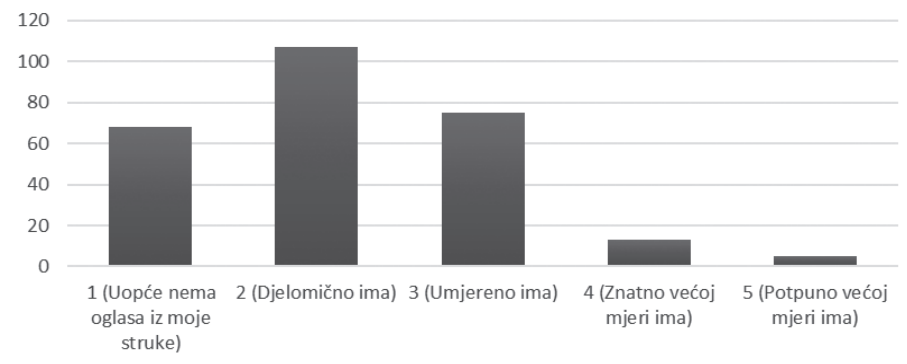

Izvor: autorice 
U grafikonu 3. prikazano je u kolikoj mjeri su objavljivani oglasi za zapošljavanje iz struke ispitanika u periodu korona pandemije. Zabilježen je odgovor 268 ispitanika. Najviše ispitanika 107 (39,9\%) smatra da su djelomično objavljivani oglasi iz njihove struke, ispitanici koji smatraju da su umjereno objavljivani oglasi 75 (28\%), ispitanici koji smatraju da uopće nije bilo oglasa iz njihove struke 68 (25,4\%), ispitanici koji smatraju da u znatno većoj mjeri ima oglasa za posao $13(4,5 \%)$ i ispitanici koji smatraju da u potpuno većoj mjeri ima oglasa za posao iz njihove struke u periodu korona pandemije 5 (1,9\%).

Na pitanja čiji su odgovori prikazani u sljedećim grafikonima odgovarali su samo ispitanici koji su zaposleni, neovisno jesu li zaposleni u struci ili izvan struke, njih ukupno 347.

Grafikon 4. Mišljenje ispitanika o povećanom broju otkaza u njihovom poduzeću

Po Vašem mišljenju u kojoj mjeri je povećan broj otkaza u Vašem poduzeću u odnosu na period prije korona pandemije (od ožujka 2020,-svibnja 2021.)?

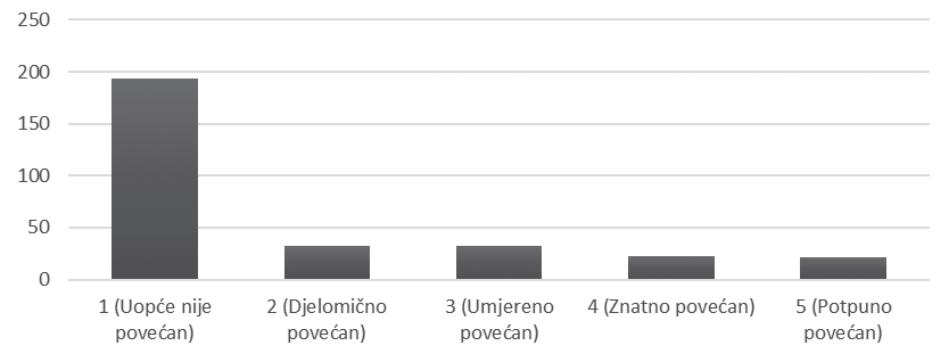

Izvor: autorice

U grafikonu 4. prikazano je mišljenje ispitanika vezano za povećanje broja otkaza u njihovom poduzeću. Najveći broj ispitanika, njih 194 (64,5\%) smatra da broj otkaza uopće nije povećan, $32(10,6 \%)$ ispitanika smatra da je djelomično povećan broj otkaza, $32(10,6 \%)$ ispitanika smatra da je umjereno povećan, 22 (7,3\%) ispitanika smatra da je znatno povećan broj otkaza te 21 (7\%) ispitanik smatra da je potpuno povećan broj otkaza u njihovom poduzeću u odnosu na period prije korona pandemije. 
Grafikon 5. Mišljenje ispitanika o povećanom broju zapošljavanja u njihovom poduzeću

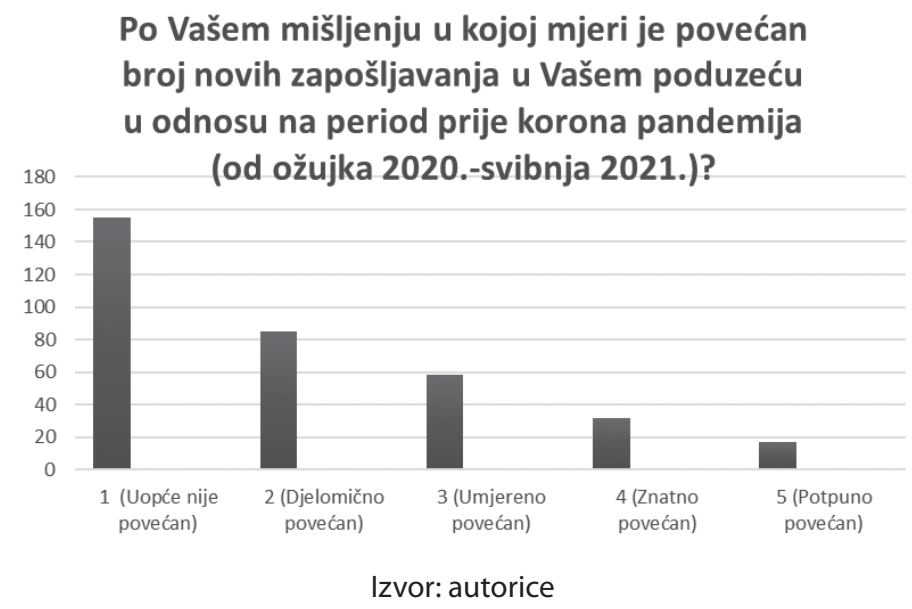

U grafikonu 5. prikazano je kako najveći broj ispitanika $155(44,7 \%)$ smatra da se broj novih zapošljavanja uopće nije povećao, 85 (24,5\%) ispitanika smatra da se djelomično povećao, $58(16,7 \%)$ ispitanika smatra da se umjereno povećao, $32(9,2 \%)$ ispitanika smatra da se znatno povećao te $17(4,9 \%)$ ispitanika smatra da se potpuno povećao.

Grafikon 6. Osjećaj ispitanika o ugroženosti njihovog radnog mjesta

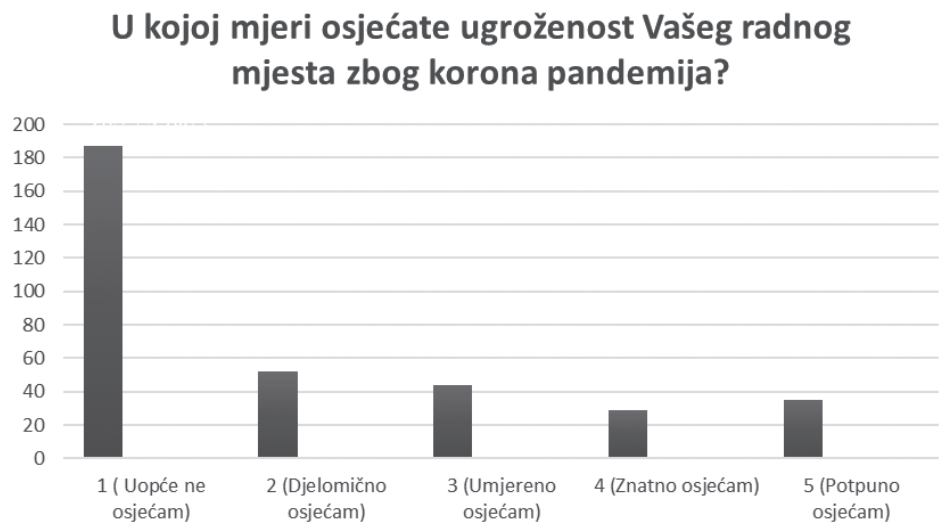

Izvor: autorice

U grafikonu 6. prikazano je da najveći broj ispitanika čak 187 (53,9\%) uopće ne osjeća ugroženost radnog mjesta zbog korona pandemije. Za pretpostaviti je da su ispitanici zadovoljni svojim radnim mjestom. 52 (15\%) ispitanika djelomično osjeća ugroženost, 44 (12,7\%) umjereno osjeća ugroženost, 29 (8,4\%) ispitanika znatno osjeća ugroženost i 35 (10,1\%) ispitanika potpuno osjeća ugroženost radnog mjesta zbog korona pandemije. 
Grafikon 7. Razmišljanje ispitanika o promjeni posla/poslodavca

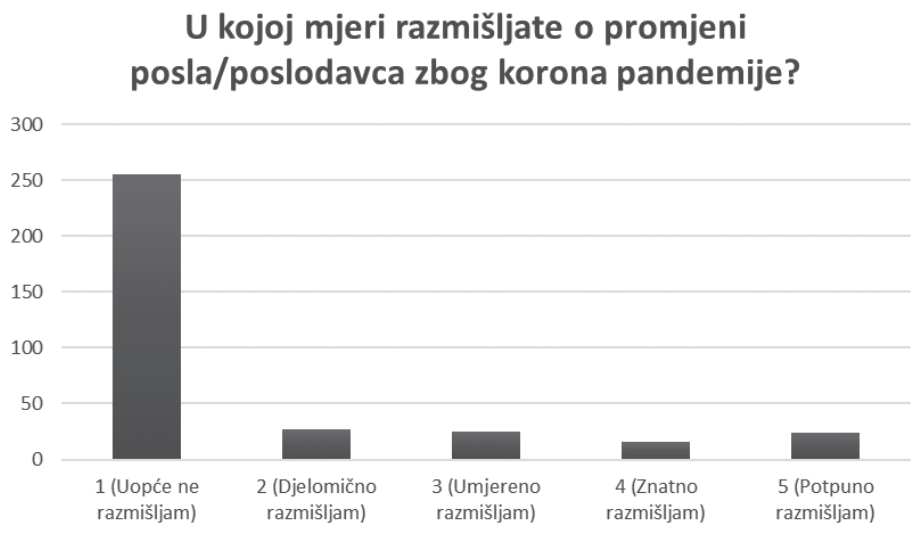

Izvor: autorice

U grafikonu 7. prikazano da najveći broj 255 (73,5\%) ispitanika uopće ne razmišlja o promjeni, 27 (7,8\%) djelomično razmišlja o promjeni, 25 (7,2\%) umjereno razmišlja o promjeni, $16(4,6 \%)$ znatno razmišlja o promjeni i 24 (6,9\%) potpuno razmišlja o promjeni posla/poslodavca. Za pretpostaviti je da je riječ o ispitanicima koji potpuno osjećaju ugroženost radnog mjesta zbog korona pandemije.

\section{Zaključak}

Korona pandemija izazvala je ozbiljnu i neočekivanu situaciju kako u pogledu zdravlja tako i u situaciji poslovanja poduzeća. To je dovelo do velikih problema u ekonomiji, a samim time i na tržištu rada. Krizom su najviše pogođene gospodarski slabije županije, i to posebno pet županija Istočne Hrvatske gdje je stopa nezaposlenosti u zadnjih pet godina bila na visokoj razini. Pojavom korona pandemije nezaposlenost se povećava, što se posebno može uočiti u 2020.godini.

Analizom upitnika radna mjesta u Istočnoj Hrvatskoj, unatoč nekim poboljšanjima, i dalje su nestabilna. Čak 43,6\% ispitanika je nezaposleno, a upravo veliki postotak njih (43,3\%) kao uzrok navode pandemiju. Postoji određeni postotak ispitanika koji osjećaju ugroženost radnog mjesta zbog korona pandemije te postoji vjerojatnost otkaza. S obzirom da ispitanici smatraju da djelomično manje poslodavci zapošljavaju u razdoblju korona pandemije te da ima manje oglasa za zaposlenje postoji mogućnost je da će se tržište rada naći u još većim poteškoćama i da će se nezaposlenost povećati. To bi moglo voditi daljnjem povećanju emigracije iz navedenih županija. Ipak takav crni scenarij jako je nezahvalno prognozirati jer pandemija još uvijek traje. Kada se stanje s pandemijom smiri, za očekivati je da će krenuti i gospodarstvo, a onda i zapošljavanje. U budućim istraživanjima predlaže se istražiti (ne)stabilnost radnih mjesta u svim županijama Republike Hrvatske uslijed djelovanja korona pandemije. 


\section{LITERATURA}

1. Hrvatska gospodarska komora (2020) Županije - razvojna raznolikost i gospodarski potencijali 2020./2021., Zagreb

2. Hrvatski zavod za zapošljavanje (2021) Mjere aktivnog zapošljavanja 2016. - 2020. Dostupno na: https://mjere.hr/o-mjerama-aktivnog-zaposljavanja/ (pristup: 25.07.2021.)

3. Hrvatski zavod za zapošljavanje, Mjesečni statistički bilten 2019., 2020., 2021.

4. Hrvatski zavod za zapošljavanje (2021) Skupna statistika isplata i radnika u potporama za očuvanje radnih mjesta - ožujak 2020.-svibanj 2021. (2021) https://mjera-zrm.hzz.hr/korisnici-potpore/skupna-statistika-korisnici-potpore-ocuvanje-radnih-mjesta/ (pristup: 02.09.2021.)

5. Svjetska banka (2020) Rast i radna mjesta u Panonskoj Hrvatskoj. Dostupno na: https:// www.worldbank.org/hr/country/croatia/brief/growth-and-jobs-in-slavonia-baranjaand-srijem (pristup: 15.08.2021.)

6. Živić, D. (2017). Demografsko pražnjenje Istočne Hrvatske. Političke analize, 8(31), 24-32.

Summary

\section{THE INFLUENCE OF THE CORONA PANDEMIC ON THE (UN)STABILITY OF WORKING PLACE IN EASTERN CROATIA}

The corona pandemic has turned into a global economic crisis, endangering above all health, the incomes of millions of people around the world, and jobs. The purpose of this paper is to understand the impact of the corona pandemic on job stability. This paper aims to analyze the impact of the corona pandemic on job stability in five counties in Eastern Croatia. The research included the analysis of a questionnaire completed by 615 respondents from 5 counties of Eastern Croatia and the collected statistical data and relevant professional literature. The limitation of the work is the fact that the pandemic is still going on and the available data are still limited. According to the results of the research, the respondents believe that the corona pandemic has a great impact on job instability in Eastern Croatia.

Keywords: pandemic, jobs, unemployment, Eastern Croatia. 